\title{
Korelasi Pemahaman Memberi Persembahan \\ Dari Lukas 21:1-4 Terhadap Partisipasi Memberi Jemaat Gereja Sidang Jemaat Allah Desa Pait - Kasembon Malang
}

\author{
Kasiatin Widianto \\ Sekolah Tinggi Teologi Injili Indonesia Surabaya \\ E-mail: kasiatinwidianto@sttii-surabaya.ac.id
}

\begin{abstract}
Abstrak. Offering made by Christians today cannot be separated from the teachings of the Bible both the Old Testament and the New Testament. Offerings should be offered seriously with full sincerity and an attitude of sacrifice. Giving offerings does not talk about how much material or wealth is given, but talks about sincerity and longing to give the best to God. The discussion of the results of quantitative research proved that the congregation of the Gereja Sidang Jemaat Allah Pait Kasembon Malang understood the doctrine of the meaning of giving offerings in the Gospel of Luke 21: 1-4 for 44.5\%, so the congregation would participate in giving offerings with the right motivation and the best quality for God. Thus the results of this study indicate that the result is in accordance with what the researcher has proposed before.
\end{abstract}

Keywords: Doctrine, Offerings, Bible, Congregation

\section{PENDAHULUAN}

Manusia pada hakikatnya adalah makhluk yang bersifat spiritual. Oleh karena itu, manusia mampu menanggapi hal-hal yang secara rohani. Manusia selalu berusaha untuk berhubungan dengan yang illahi. Sehingga hubungan dengan yang illahi tersebut diwujudkan dalam bentuk ibadah.

Konsep ibadah baik dalam Perjanjian Lama maupun Perjanjian Baru memiliki konsep yang sama. Kata Ibrani עָבָב (abad) dan Yunani $\lambda \alpha \tau \rho \varepsilon \iota \alpha$ (latreia) pada mulanya menyatakan pekerjaan seorang budak. Dan dalam rangka mempersembahkan 'ibadat' kepada Allah, maka para hamba-Nya harus meniarap, sebagai ungkapan rasa takut penuh hormat, kekaguman dan ketakjuban penuh puja. ${ }^{1}$ Konsep inilah yang mendasari tindakan seseorang dalam setiap kegiatan memberikan korban persembahan dalam setiap ibadah.

\footnotetext{
${ }^{1}$ Ensiklopedi Alkitab Masa Kini Jilid I
} (Jakarta: Yayasan Komunikasi Bina Kasih/OMF, 1992), 409.
Demikian juga berkaitan dengan pelaksanaan ibadah yang dilakukan oleh orang yang percaya kepada Tuhan Yesus. Persembahan menjadi suatu bagian dalam setiap kegiatan ibadah yang tidak terpisahkan. Hal tersebut dikarenakan memberi persembahan memiliki makna yang tidak hanya sekedar memberi atau membawa, baik berupa uang atau barang yang lain kepada Tuhan. Namun, tindakan manusia dalam memberi kepada Tuhan harus disertai dasar dan keyakinan yang benar terhadap Tuhan, dan tidak dapat dikerjakan secara asal-asalan.

Mengingat hampir semua kegiatan ibadah, mulai dari ibadah anak-anak, ibadah pemuda remaja, ibadah ibu-ibu, ibadah lansia, ibadah umum hari Minggu, ibadah pendalaman Alkitab dan masih banyak yang lain: 'memberikan persembahan' telah menjadi bagian dalam liturgi ibadah. Maka dari itu memberikan persembahan harus dipahami secara benar dan sungguhsungguh. Karena kalau tidak akan mengurangi, 
bahkan akan kehilangan makna dari ibadah itu sendiri.

Salah satu bagian terpenting dari kedewasaan kerohanian ialah memahami kuasa dan relevansi Firman Tuhan bagi orang percaya pada saat ini, dalam setiap aspek kehidupannya. Belajar firman Tuhan juga tidak dapat dilakukan secara instan, tetapi melalui proses yang panjang. Karena sepanjang kehidupan manusia harus terus belajar menuju pada kesempurnaan yang sesuai dengan kebenaran. Setiap orang percaya yang bertumbuh kerohaniannya akan memiliki kerinduan dan komitmen yang kuat untuk terus belajar firman Tuhan. Setiap firman Tuhan dipelajari maka ada banyak hal yang dapat diperoleh dari kebenaran firman Tuhan. Segala asal pengetahuan adalah dari firman Tuhan.

Secara umum ibadah dipahami sebagai perbuatan yang menyatakan bakti kepada Allah, yang dilandasi oleh sikap ketaatan untuk menjalankan perintah-perintah-Nya dan menjauhi larangan-larangan-Nya. ${ }^{2}$ Sehingga dengan demikian dapat dikatakan memberikan persembahan telah menjadi suatu tindakan atau pelaksanaan yang menuntut penyerahan dari si pelaku.

Oleh sebab itu memberi persembahan dapat dimaknai sebagai ungkapan yang mendalam dari manusia dalam hubungannya kepada Tuhan. Makna tersebut berdasar kepada arti dari ibadah itu sendiri. Ibadah Kristen adalah keikutsertaan umat di dalam tindakan Imamat Kristus demi kepentingan manusia sendiri, sebagai ajakan kepada umat untuk menjadi korban yang hidup di dalam kehidupanya. $^{3}$ Maka memberikan

\footnotetext{
${ }^{2}$ Peter Salim dan Yenny Salim, Kamus
}

Bahasa Indonesia Kontemporer (Jakarta: Modern English Press, 1991), 1371.

${ }^{3}$ Gerald O,Collins. SJ dan Edward G.

Farrugia, SJ. Kamus Teologi (Jakarta: Kanisius, 1996), 109. persembahan yang telah menjadi bagian yang tidak terpisah dalam ibadah, menjadi tindakan dari orang percaya yang tidak dapat dianggap sepele. Oleh sebab itu dasar pemahaman dan motivasi yang benar dalam memberikan persembahan kepada Tuhan, harus dimiliki oleh setiap orang Kristen.

\section{Latar Belakang Masalah}

Persembahan yang dilakukan oleh orang Kristen saat ini tidak dapat terlepas dari ajaran Alkitab baik Perjanjian Lama maupun Perjanjian Baru. Dalam Kitab Kejadian 4:3-4, memberikan penjelasan bahwa jauh sebelum gereja ada, keturunan Adam dan Hawa dalam hal ini Kain dan Habel telah melaksanakan korban yang dipersembahkan kepada Tuhan. Tokoh-tokoh Alkitab yang selanjutnya Nuh, Abraham dan bangsa Israel meneruskan pola ibadah yang disertai korban tersebut. Namun demikian dalam perkembangannya, pemazmur dan para nabi Perjanjian Lama yang saleh tidak melihat nilai apa pun dalam korban, jika persembahan korban tersebut diselewengkan dan disalahgunakan. Ikatan batiniah atau hubungan pribadi penyembah dengan Tuhan merupakan prioritas dalam memberikan korban persembahan. ${ }^{4}$ Menurut John Drane, makna pengorbanan dalam Perjanjian Lama adalah suatu cara simbolis yang memungkinkan orang berdosa dipulihkan hubungannya dengan Allah. ${ }^{5}$

Dalam Perjanjian Baru korban-korban persembahan masih dilaksanakan, bahkan Tuhan Yesus mempersembahkan korban pada Paskah terakhir. Kristus dikatakan Domba Allah yang disembelih, darah-Nya yang suci meniadakan dosa dunia (Yoh. 1:29, 36; I Ptr. 1:18; Wah. 5:6-

${ }^{4}$ Ensiklopedi Alkitab Masa Kini Jilid 1 A-L, 580.

5 John Drane, Memahami Perjanjian BaruPengantar Historis Teologis (Jakarta: BPK Gunung Mulia, 2012), 98. 
10; 13:8). ${ }^{6}$ Kematian Yesus merupakan penggenapan sejati dari apa yang dilambangkan dalam Perjanjian Lama. Orang Kristen mengetahui bahwa telah diperdamaikan dengan Allah melalui korban Tuhan.

Sebagai umat yang dijadikan baru, maka harus mempersembahkan diri kepada Tuhan. ${ }^{7}$ Inilah yang dimaksudkan oleh Rasul Paulus, “... supaya kamu mempersembahkan Tubuhmu sebagai persembahan yang hidup, yang kudus dan yang berkenan kepada Allah..." Roma 12:1. Melihat bahwa korban persembahan berkaitan dengan ibadah, maka sikap penyerahan hidup kepada Tuhan menjadi kunci dari semua persembahan.

Dengan dasar korban Kristus untuk manusia, maka persembahan kepada Tuhan, merupakan ungkapan syukur, dan sebagai tanggung jawab atas anugerah yang Allah berikan kepada manusia. Karena sangat tidak mungkin korban persembahan manusia dapat melepaskanya dari kematian akibat dosa. Kepercayaan orang Kristen, akan pengorbanan Tuhan Yesus di kayu salib yang menanggung dosa-dosa manusia, memberikan dasar sikap dan motifasi orang Kristen tersebut dalam memberi persembahan.

Dengan demikian memberikan persembahan berhubungan langsung dengan pertumbuhan rohani orang percaya. Karena kesediaan umat Tuhan untuk memberikan korban persembahan merupakan akibat langsung dari pengalaman iman yang dipelihara oleh kasih setia Tuhan Yesus yang telah rela mati untuk seluruh umat manusia. ${ }^{9}$ Maka dari itu merupakan

581.

\section{${ }^{6}$ Ensiklopedi Alkitab Masa Kini Jl 1 A-L,}

\footnotetext{
${ }^{7}$ John Drane, Memahami Perjanjian BaruPengantar Historis Teologis, 98. (Jakarta: LAI, 1993).

${ }^{8}$ Alkitab Bahasa Indonesia Terjemahan Baru

${ }^{9}$ Jian Wiharja, Persembahan yang Baik dan Benar (Bandung: Yayasan Kalam Hidup, 1993), 27.
}

kesukaan tersendiri jika umat Tuhan masih diberikan kesempatan untuk mengungkapkan syukur mereka kepada Tuhan. Dan merupakan suatu tanggung jawab, jika manusia masih dipercayakan untuk menikmati sebagian dari milik Tuhan.

Kesadaran orang Kristen akan semua yang ada dalam hidupnya adalah milik Allah, menjadikan orang tersebut memiliki tanggung jawab yang benar akan semua yang mereka miliki. Mazmur 50:10-12 mengatakan: “ ... sebab punya-Kulah dunia dan segala isinya". Pengakuan iman bahwa Tuhan pencipta langit bumi dan segala isinya, dan kepercayaan bahwa Tuhan Yesus Kristus telah menebus manusia berdosa akan membawa orang percaya memahami bahwa semua yang ada pada mereka adalah milik Allah. ${ }^{10}$ Dengan demikian dasar memberikan persembahan adalah dengan sukacita dan penuh kerelaan.

Namun sampai saat ini, masih ada umat Tuhan yang belum begitu menyadari betapa pentingnya memberikan persembahan yang benar. Demikian juga, masih dijumpai anak-anak Tuhan yang secara ekonomi sangat mampu, namun belum dapat memberikan persembahan dengan baik. Mereka hanya sekedar memberi persembahan, bahkan persembahan tersebut tidak memiliki nilai berarti bagi diri mereka. Masih kurangnya kesadaran umat Tuhan akan semua yang ada padanya adalah milik Tuhan, membuat kurangnya tanggung jawab mereka akan pekerjaan Tuhan secara menyeluruh. Sehingga persembahan hanya dipahami dengan arti yang sempit. Persembahan hanya dipahami sebagai suatu tindakan memberikan uang atau materi yang lain secara asal-asalan.

Persembahan seharusnya menjadi milik Tuhan dan untuk kegiatan pekerjaan Tuhan secara menyeluruh. Persembahan yang 
seharusnya dipersembahkan oleh umat Tuhan sebagai ungkapan syukur yang keluar dari hati yang murni dan tulus dan penuh pengorbanan, dapat menjadi suatu kebiasaan yang tidak berarti di hadapan Tuhan. Menurut Pdt. Y. M. Imanuel Sukardi di dalam buku Rahasia Investasi Tanpa Rugi, dikatakan: "Persembahan adalah merupakan pemberian yang memilukan yang dilakukan oleh kebanyakan orang Kristen. ${ }^{11}$ Ada orang-orang Kristen yang menganggap ringan atau tidak penting dalam memberikan persembahan. Ketika mereka datang dalam sebuah kebaktian dalam Rumah Tuhan, dan ketika tiba saatnya mereka harus memberikan persembahan, mereka hanya memberikan yang terkecil dari uang yang ada pada mereka. Pemberian mereka tidak jauh berbeda ketika memberikan uang kepada pengemis yang ada di jalanan. Padahal memberi kepada pengemis adalah pemberian yang tidak diharapkan oleh kedua belah pihak. Hal tersebut sama ketika jemaat memberi dengan asal-asalan kepada Tuhan, bagi jemaat juga tidak berarti terlebih di hadapan Tuhan. ${ }^{12}$

Namun di lain sisi ada jemaat yang memberikan dengan luar biasa banyaknya. Pemberian persembahan mereka jauh di atas ratarata jemaat lain. Namun dibalik semua pemberian tersebut ada motif lain selain untuk Tuhan. Ada jemaat yang senang mendapat pujian karena mereka memberi persembahan lebih besar dari yang lain. Ada juga yang beranggapan ketika mereka memberi persembahan yang besar, mereka juga akan menerima lebih besar lagi. Hal tersebut seperti yang diungkapkan oleh Larry Burkett dalam bukunya 'Mengatur Keuangan dengan Bijak'. ${ }^{33}$ Dalam hal ini dasar yang

\footnotetext{
${ }^{11}$ Pdt. YM. Imanuel Sukardi, Rahasia
} Investasi Tanpa Rugi (Surakarta: STT Indonesia, 2004), 3.

12 Benny Santoso dan Wiyono Pontjoharyo, All About Money (Yogyakarta: PBMR Andi, 2002), 217.

${ }^{13}$ Larry Burkett, Mengatur Keuangan Dengan Bijak (Bandung: Yayasan Kalam Hidup, 1993), 308. mendorong jemaat untuk memberi persembahan harus benar, persembahan hanya tertuju kepada Tuhan. Memberi kepada Allah adalah suatu kewajiban. Dan yang diberikan oleh orang-orang beriman itu adalah apa yang menjadi milik atau bagian Allah (Luk. 20:20-26).

Dengan demikian memberikan persembahan merupakan suatu tanggung jawab yang telah Tuhan ajarkan kepada umat-Nya. Hal tersebut juga disampaikan oleh, Wiharja Jian yang mengatakan: "Membawa persembahan, ibadah, dan kekudusan, semuanya berkaitan erat dengan rencana Allah bagi kehidupan kita. ${ }^{14}$

Di atas telah sedikit disinggung bagaimana manusia pada awalnya telah memberikan persembahan kepda Tuhan. Hal tersebut sebagai wujud manusia dalam mengungkapkan rasa syukur akan anugerah Tuhan dan sekaligus rasa hormat, takut, kagum akan kebesaran Tuhan. Dan sebagai bukti kelemahan dan ketidakberdayaan manusia sehingga harus membutuhkan Tuhan. Kebutuhan manusia terhadap Tuhan terungkap dalam tindakan mempersembahkan korban dalam ibadah. Hal inilah yang seharusnya diketahui dan disadari oleh semua orang yang percaya kepada Tuhan Yesus, bahwa persembahan mereka seharusnya menjadi suatu persembahan yang layak dan terbaik untuk dipersembahkan kepada Tuhan. Persembahan tersebut harus memiliki nilai pengorbanan yang diperuntukkan kepada Tuhan.

Melihat pentingnya memberikan persembahan kepada Tuhan, gereja memiliki peran penting untuk mengajarkan persembahan. Faktor lamanya seseorang menjadi orang Kristen tidak dapat menentukan kedewasaan dan ketaatan dalam memberi persembahan kepada Tuhan. Kebenaran-kebenaran tentang persembahan perlu diajarkan kepada orang-orang Kristen sejak ia

${ }^{14}$ Jian Wiharja, Persembahan yang Baik dan benar Dari Tuhan untuk Tuhan (Bandung: Yayasan Kalam Hidup, 2001), 21. 
mulai menjadi orang Kristen. ${ }^{15}$ Sehingga dengan demikian jemaat dapat memahami dengan benar apa dan bagaimana seharusnya memberi persembahan kepada Tuhan.

Persembahan seharusnya dipersembahkan secara sungguh-sungguh dengan penuh ketulusan hati dan sikap pengorbanan. Memberi persembahan tidak berbicara mengenai berapa banyaknya materi atau harta kekayaan yang diberikan, namun berbicara mengenai ketulusan dan kerinduan untuk memberikan yang terbaik kepada Tuhan.

Keadaan ekonomi jemaat yang kurang mampu, tidak dapat menjadi alasan untuk tidak memberikan persembahan. Karena Alkitab telah mengajarkan kepada orang Kristen, mengenai persembahan jemaat miskin sesuai yang telah dikatakan oleh Rasul Paulus dalam 2 Korintus 8:1-5: "Saudara-saudara, kami hendak memberitahukan kepada kamu tentang kasih karunia yang dianugerahkan kepada jemaatjemaat di Makedonia. Selagi dicobai dengan berat dalam pelbagai penderitaan, sukacita mereka meluap dan meskipun mereka sangat miskin, namun mereka kaya dalam kemurahan. Aku bersaksi, bahwa mereka telah memberikan menurut kemampuan mereka, bahkan melampaui kemampuan mereka. Dengan kerelaan sendiri mereka meminta dan mendesak kami, supaya mereka juga beroleh kasih karunia untuk mengambil bagian dalam pelayanan kepada orang-orang kudus. Mereka memberikan lebih banyak daripada yang kami harapkan”.

Dari ayat di atas dapat diketahui bahwa jemaat Makedonia dalam kondisi ekonomi yang kekurangan, namun dapat memberikan persembahan yang terbaik. Hal tersebut bukan karena paksaan namun karena mereka telah menerima pengajaran firman Tuhan yang telah

\footnotetext{
${ }^{15}$ Nehemiah Mimery, Persembahan dan Pemakaian Uang Tuhan (Jakarta: Mimery Press,t.t), hal 12.
}

disampaikan oleh rasul-rasul. Pemahaman jemaat terhadap firman Tuhan, akan berdampak kepada respon mereka terhadap memberikan persembahan bagi Tuhan.

Dengan berpartisipasi memberikan persembahan kepada Tuhan, tidak akan mengakibatkan jemaat yang tadinya miskin akan bertambah miskin lagi. Namun sebaliknya, justru mereka menjadi bertambah kaya dalam iman. Dasar yang mereka pakai adalah memberi dengan hati yang rela dan jumlahnya tidak sama, sebab masing-masing memberi menurut kemampuan masing-masing. Dalam memberi mereka tidak memakai prinsip untung rugi, pelayanan kepada Tuhan saja yang membuat mereka dapat memberi persembahan.

Di atas penulis telah menjelaskan sedikit, bahwa persembahan berkaitan dengan kerelaan dari hati yang siap berkorban untuk Tuhan. Jadi sikap hati yang sangat menentukan, sehingga persembahan tidak dapat diukur banyak dan sedikitnya harta, materi atau uang. Dengan demikian, untuk jemaat Tuhan yang benar-benar tidak mampu tidak dituntut untuk memberikan banyak. Namun demikian ketidak mampuan seseorang tidak dapat dijadikan alasan untuk memberikan persembahan kepada Tuhan.

Oleh karena itu dapat dicapai suatu kesimpulan, bahwa semua orang percaya kepada Tuhan Yesus, memiliki kesempatan yang sama untuk dapat memberikan persembahan yang terbaik untuk Tuhan. Tuhan Yesus memuji janda miskin, yang hanya memberikan persembahan dengan memasukkan dua peser ke dalam peti persembahan di bait Allah. Suatu keadaan yang sangat kontras, jika dibandingkan dengan kebanyakan orang yang memberi persembahan dengan jumlah yang besar. Namun demikian, janda miskin tersebut memuji Tuhan dengan seluruh yang dia miliki. Uang dua peser, yang dipersembahkan kepada Tuhan, adalah seluruh nafkah hidupnya pada hari itu. 
Dengan melihat kasus- kasus yang berhubungan dengan persembahan orang percaya kepada Tuhan, melalui pekerjaan Tuhan dalam hal ini gereja, maka penulis sangat tertarik untuk mengkaji firman Tuhan dalam Injil Lukas 21:1-4 mengenai memberi persembahan dan membuat suatu penelitian terhadap jemaat Tuhan, sehingga dapat diketahui permasalahan- permasalahan yang sesungguhnya terjadi.

Dengan demikian, penulis dapat membuat suatu kesimpulan berkaitan dengan memberi persembahan yang benar sesuai dengan Alkitab sebagai sumber dan dasarnya. Sehingga dapat diambil suatu langkah dalam melaksanakan memberi persembahan secara benar sesuai dengan Firman Tuhan.

\section{Identifikasi Masalah}

Dengan melihat latar belakang masalah tersebut di atas, maka peneliti dapat mengetahui permasalahan-permasalahan yang terjadi dalam jemaat Tuhan, yang berhubungan dengan persembahan.

Masih adanya orang Kristen yang belum memahami arti persembahan yang benar kepada Tuhan. Hal tersebut akan berdampak langsung terhadap kedewasaan iman jemaat kepada Tuhan. Persembahan seharusnya memiliki nilai pengorbanan dan ungkapan syukur yang sangat dalam bagi jemaat Tuhan. Namun hal tersebut akan menjadi suatu tindakan yang tidak berarti, bila dilakukan hanya sekedar rutinitas atau hanya asal-asalan saja. Demikian juga, masih ada jemaat yang tidak mau memberi persembahan kepada Tuhan dengan alasan miskin.

\section{Batasan Masalah}

Mengingat luasnya permasalahan yang telah diuraikan di atas, maka peneliti perlu membatasi permasalahan yang akan diteliti, yakni “Ajaran Alkitab Tentang Memberi Persembahan menurut Lukas 21:1-4 dan
Korelasinya terhadap partisipasi jemaat dalam memberi di Gereja Sidang Jemaat Allah desa Pait Kasembon-Malang."

\section{Rumusan Masalah}

Berdasarkan latar belakang yang telah dipaparkan di atas, berkaitan dengan pemahaman bahwa persembahan merupakan suatu hal yang tak terpisahkan dari ibadah terhadap Tuhan dan menjadi suatu keharusan bagi jemaat untuk memberikan yang terbaik bagi Tuhan, maka penulis mengajukan rumusan masalah, sebagai berikut.

Pertama, apakah ada pengaruh jemaat sudah memiliki pemahaman yang benar mengenai memberi persembahan sesuai Injil Lukas 21:1-4?

Kedua, ada berapa persen jemaat yang berpartisipasi dalam memberi persembahan seperti prinsip memberi persembahan dalam Injil Lukas 21:1-4?

\section{Metode Penelitian}

Dengan demikian untuk mencapai sasaran yang di inginkan dalam penulisan ini penulis menggunakan metode riset ilmiah untuk menyelidiki variabel-variabel yang dipilih untuk di teliti. Methode riset ilmiah disamakan dengan penggunaan metode riset kuantitatif. ${ }^{16}$

\section{Tempat dan Waktu Penelitian}

Tempat sebagai objek penelitian ini dilaksanakan di Gereja Sidang Jemaat Allah (GSJA) desa Pait Kasembon Malang. Adapun waktu pelaksanaannya bulan Febuari 2014 sampai dengan Agustus 2014.

\footnotetext{
${ }^{16}$ Paticia Ann Dempsey dan Arthur D. Dempsey, Riset Keperawatan (Jakarta: Penerbit Buku Kedokteran EGC, 1997), alih Palupi Widyastuti,33.
} 


\section{Populasi dan Sampel}

Dengan demikian sesuai judul penelitian ini, maka yang menjadi obyek atau target penelitian ini adalah jemaat dewasa GSJA Pait Kasembon Malang yang berjumlah empat puluh lima jiwa.

\begin{tabular}{|c|c|c|}
\hline Keterangan & Jumlah & $\begin{array}{c}\text { Persentase } \\
(\%)\end{array}$ \\
\hline Laki-laki & 16 & 35,6 \\
\hline Perempuan & 29 & 64.4 \\
\hline Total & 45 & 100 \\
\hline
\end{tabular}

\begin{tabular}{|c|c|c|}
\hline Keterangan & Jumlah & $\begin{array}{c}\text { Persentase } \\
(\%)\end{array}$ \\
\hline Laki-laki & 16 & 35,6 \\
\hline Perempuan & 29 & 64.4 \\
\hline Total & 45 & 100 \\
\hline
\end{tabular}

\begin{tabular}{|c|c|c|}
\hline Keterangan & Jumlah & $\begin{array}{c}\text { Persentase } \\
(\%)\end{array}$ \\
\hline Laki-laki & 16 & 35,6 \\
\hline Perempuan & 29 & 64.4 \\
\hline Total & 45 & 100 \\
\hline
\end{tabular}

\begin{tabular}{|c|c|c|}
\hline Pekerjaan & Jumlah & $\begin{array}{c}\text { Persentase } \\
(\%)\end{array}$ \\
\hline PNS & 1 & 2.2 \\
\hline Swasta & 7 & 15.6 \\
\hline Petani & 14 & 31.1 \\
\hline Wiraswasta & 11 & 24.4 \\
\hline Lain-lain & 12 & 26.7 \\
\hline Total & 45 & 100 \\
\hline
\end{tabular}

\begin{tabular}{|c|c|c|}
\hline $\begin{array}{c}\text { Lama } \\
\text { Berjemaat }\end{array}$ & Jumlah & $\begin{array}{c}\text { Persentase } \\
(\%)\end{array}$ \\
\hline 2-5 tahun & 1 & 2.2 \\
\hline 6-10 tahun & 2 & 4.4 \\
\hline $11-15$ tahun & 5 & 11.1 \\
\hline$>16$ tahun & 37 & 82.2 \\
\hline Total & 45 & 100.0 \\
\hline
\end{tabular}

\section{Tujuan Penelitian}

Tujuan dari penelitian ini adalah untuk mengetahui, bagaimana pemahaman untuk memberi persembahan yang benar, sesuai dengan prinsip memberi persembahan dalam Injil Lukas 21:1-4. Dan juga untuk mengetahui sejauh mana gembala sidang mengajarkan hal memberi persembahan yang benar, seperti prinsip memberi persembahan dalam Injil Lukas 21:1-4.

Bagi jemaat sebagai pelaku Firman Tuhan, dapat diketahui sudahkah jemaat memiliki pemahaman yang benar mengenai memberi persembahan. Dan untuk mengetahui juga, apakah jemaat sudah memiliki kerelaan hati dalam memberi persembahan kepada Tuhan seperti yang dicontohkan dalam Injil Lukas 21:14.

Dengan demikian akan diketahui, sejauh mana hubungan antara memberi persembahan dalam Injil Lukas 21:1-4 dengan partisipasi jemaat Gereja Sidang-sidang Jemaat Allah dalam memberi persembahan kepada Tuhan.

Sehingga melalui penelitian ini dapat diambil suatu kesimpulan mengenai memberikan persembahan, dan hubunganya dengan ketaatan jemaat dalam memberi persembahan kepada Tuhan. Diharapkan juga melalui kajian Firman Tuhan dalam Injil Lukas 21:1-4, dapat dijadikan suatu teladan bagi jemaat Tuhan dalam sikap dan motivasi dalam memberi persembahan kepada Tuhan. Sehingga diharapkan tidak ada lagi jemaat yang memberikan persembahan kepada Tuhan dengan asal-asalan, dalam arti tidak memiliki kerinduan untuk memberikan yang terbaik bagi Tuhan

\section{Manfaat Hasil Penelitian}

Diharapkan dari hasil penelitian yang dilakukan di jemaat Gereja Sidang Jemaat Allah Pait Kasembon-Malang membawa manfaat bagi banyak pihak. Pertama, bagi gembala sidang atau pemimpin rohani gereja setempat, agar dapat menjadi suatu masukan atau bahan perbandingan sehubungan dengan ketaatan jemaat dalam memberikan persembahan kepada Tuhan, dan 
mengetahui faktor-faktor yang mempengaruhi tingkat kualitas dan kuantitas persembahan jemaat. Sehingga dengan demikian dapat diambil langkah- langkah untuk membawa jemaat, untuk taat dan memberikan yang terbaik kepada Tuhan.

Kedua, kiranya bermanfaat bagi jemaat setempat, kiranya setelah membaca hasil penelitian ini diharapkan memiliki pemahaman yang benar dalam memberi persembahan, dan memiliki kerinduan, kerelaan untuk memberikan persembahan kepada Tuhan, seperti persembahan janda miskin dalam Injil Lukas 21:1-4.

Selanjutnya, kiranya hasil penelitian ini pun bermanfaat pada seluruh pembaca setidaknya mendadapatkan informasi mengenai persembahan dan praktek dalam jemaat. Sehingga setiap pembaca dapat menarik suatu kesimpulan untuk dijadikan sebagai acuan, tindakan atau aplikasi dalam kehidupan mengenai bagaimana seharusnya manusia sebagai umat dalam memberikan persembahan kepada Tuhan, Sang Khalik dan Sang Sumber berkat.

\section{Analisa Data}

Peneliti menganalisis uji persyaratan analisis untuk mengetahui apakah masing-masing variabel ini memenuhi persyaratan atau tidak. Untuk mengadakan Uji persyaratan analisis yang dilakukan di sini adalah uji Validitas dan uji Reliabilitas.

Instrumen dinyatakan reliabel apabila koefesien Cronbach's Alfa (r) $\geq 0,6$. Sedangkan untuk menguji validitas butir-butir pertanyaan dapat dilihat pada Corrected Item-Total Correlation, dinyatakan valid atau sah apabila nilai korelasi $\geq 0,2$.

Reliability Statistics
\begin{tabular}{|l|l|}
\hline $\begin{array}{l}\text { Cronbach's } \\
\text { Alpha }\end{array}$ & N of Items \\
\hline 658 & 10 \\
\hline
\end{tabular}

Nilai reliabilitas dilihat dari koefisien Cronbach's Alfa. Dengan jumlah pernyataan $(\mathrm{N})$ sebanyak 10, koefisien Cronbach's Alfa (r) sebesar 0,658 > 0,6 maka semua instrumen dalam variabel $X$ dinyatakan reliabel. 


\begin{tabular}{|c|c|c|c|c|c|}
\hline & $\begin{array}{c}\text { Scale Mean if } \\
\text { Item Deleted }\end{array}$ & $\begin{array}{c}\text { Scale } \\
\text { Variance if } \\
\text { Item Deleted }\end{array}$ & $\begin{array}{c}\text { Corrected } \\
\text { Item-Total } \\
\text { Correlation }\end{array}$ & $\begin{array}{c}\text { Cronbach's } \\
\text { Alpha if Item } \\
\text { Deleted }\end{array}$ & Keterangan \\
\hline X1 & 75.20 & 15.664 & .225 & .648 & valid \\
X3 & 75.09 & 14.719 & .468 & .622 & valid \\
X4 & 75.33 & 15.318 & .226 & .648 & valid \\
X5 & 75.09 & 15.265 & .322 & .638 & valid \\
X6 & 75.02 & 15.477 & .271 & .643 & valid \\
X7 & 75.07 & 15.018 & .388 & .631 & valid \\
X8 & 75.07 & 15.427 & .280 & .642 & valid \\
X9 & 75.09 & 15.037 & .382 & .631 & valid \\
X10 & 77.42 & 16.113 & .075 & .665 & tidak valid \\
\hline
\end{tabular}

Seluruh nilai dalam kolom Corrected ItemTotal Correlation (korelasi butir dengan total butir) memiliki nilai $>0,2$ sehingga seluruh butir pernyataan dalam variabel $\mathrm{X}$ dinyatakan valid, kecuali satu dari butir X.10 yang memilki nilai $0.075<0.2$ sehingga butir X.10 dinyatakan tidak valid. Kecuali instrumen X "Ajaran Alkitab Tentang memberi Persembahan Menurut Injil Lukas 21:1-4" memiliki nilai lebih kecil dari 0,2, sehingga instrumen X "Ajaran Alkitab Tentang Memberi Persembahan Menurut Injil Lukas 21:14" dinyatakan tidak valid.

\section{Uji Reliabilitas}

Reliability Statistics

Reliability Statistics

\begin{tabular}{|r|r|}
\hline \multicolumn{1}{|c|}{$\begin{array}{c}\text { Cronbach's } \\
\text { Alpha }\end{array}$} & N of Items \\
\hline .670 & 20 \\
\hline
\end{tabular}

Nilai relibilitas dilihat dari koefisien Cronbach's Alfa. Dengan jumlah pernyataan (N) sebanyak 20, koefisien Cronbach's Alfa (r) sebesar $0.670>0.6$ maka semua instrumen dalam variabel Y dinyatakan reliabel. 
Uji Validitas

\begin{tabular}{|l|l|l|l|l|l|}
\hline & $\begin{array}{l}\text { Scale Mean if } \\
\text { Item Deleted }\end{array}$ & $\begin{array}{l}\text { Scale } \\
\text { Variance if } \\
\text { Item Deleted }\end{array}$ & $\begin{array}{l}\text { Corrected } \\
\text { Item-Total } \\
\text { Correlation }\end{array}$ & $\begin{array}{l}\text { Cronbach's } \\
\text { Alpha if Item } \\
\text { Deleted }\end{array}$ & Keterangan \\
\hline Y1 & 75.47 & 15.391 & .475 & .632 & valid \\
Y2 & 75.47 & 15.209 & .449 & .630 & valid \\
Y3 & 75.22 & 15.359 & .274 & .642 & valid \\
Y4 & 75.16 & 14.634 & .445 & .623 & valid \\
Y5 & 76.91 & 15.356 & .080 & .681 & valid \\
Y6 & 77.47 & 15.391 & .105 & .672 & valid \\
Y7 & 77.60 & 16.245 & .106 & .658 & valid \\
Y8 & 75.47 & 16.800 & -.078 & .684 & Tidak valid \\
Y9 & 75.22 & 15.813 & .123 & .660 & valid \\
Y10 & 74.84 & 15.862 & .214 & .649 & valid \\
\hline
\end{tabular}

Seluruh nilai dalam kolom Corrected Item-total Correlation (korelasi butir dengan total butir) memilki nilai >0,2 sehingga sembilan puluh persen butir pernyataan dalam variabel Y dinyatakan valid. Sedangkan sepuluh persen (satu item/ Y.8) memiliki nilai -0.078 dinyatakan tidak valid karena memiliki nilai korelasi $<0.2$

\section{Uji Korelasi}

Uji Hubungan Variabel X Dan Y

Correlation

\begin{tabular}{|c|c|c|}
\hline & $\begin{array}{l}\text { X" Ajaran Alkitab Tentang } \\
\text { Memberi Persembahan } \\
\text { Menurut Injil Lukas 21:1-4" }\end{array}$ & $\begin{array}{l}\text { Y" Korelasinya Terhadap } \\
\text { Partisipasi Jemaat Gereja } \\
\text { Sidang Jemaat Allah Pait } \\
\text { Kasembon Malang Dalam } \\
\text { Memberi" } \\
\end{array}$ \\
\hline $\begin{array}{l}\text { X "Ajaran Alkitab } \\
\text { Tentang Memberi } \\
\text { Persembahan Menurut } \\
\text { Injil Lukas 21:1-4". } \\
\text { Pearson Correlation } \\
\text { sig, (2-tailed) N }\end{array}$ & 1 & 0,367 \\
\hline $\begin{array}{l}\text { Y "Korelasinya } \\
\text { Terhadap Partisipasi } \\
\text { Jemaat Gereja Sidang- } \\
\text { sidang Jemaat Allah } \\
\text { Pait Kasembon } \\
\text { Malang dalam }\end{array}$ & 0,367 & 1 \\
\hline
\end{tabular}




\begin{tabular}{|l|r|}
\hline $\begin{array}{l}\text { Memberi” Pearson } \\
\text { Correlation sig, }(2- \\
\text { tailed) N }\end{array}$ & 0,013 \\
\hline$* *$ Correlation is significant at the 0,01 level $(2-$ tailed $)$ \\
\hline
\end{tabular}

**. Correlation is significant at the 0,01 level (2-tailed)

Pedoman untuk memberikan interpretasi koefisien korelasi sebagai berikut:

$0,00-0,199=$ sangat rendah

$0,20-0,399=$ rendah

$0,40-0,599=$ sedang

$0,60-0,799=$ kuat

$0,80-1,000=$ sangat kuat.

\section{Pengujian Hipotesa}

Berdasarkan hasil penelitian pada Pearson Correlation di atas, maka dapat diketahui bahwa kecenderungan pemahaman responden Jemaat Gereja Sidang-sidang Jemaat Allah Pait Kasembon Malang" mengenai $\mathrm{X}$ terhadap $\mathrm{Y}$, adalah $\mathrm{R}=1$.

Jadi hubungan pemahaman responden jemaat Gereja Sidang-sidang Jemaat Allah Pait Kasembon Malang tentang Ajaran Alkitab Tentang Memberi Persembahan Menurut Injil Lukas 21:1-4 (X) dengan "Korelasinya Terhadap Partisipasi dalam memberi di Jemaat GSJA Pait Kasembon Malang" $Y$ tersebut di atas $(\mathrm{R}=1)$ termasuk pada kategori "sangat kuat" dalam interval 0,80-1,000.

\section{Pembahasan}

Pembahasan dari hasil deskriptif data, analisis data serta pengujian hipotesis yang diperoleh membuktikan bahwa jemaat Gereja Sidang Jemaat Allah Pait Kasembon Malang memahami ajaran tentang arti memberi persembahan dalam Injil Lukas 21:1-4 sebesar $44.5 \%$, sehingga jemaat akan berpartisipasi dalam memberi persembahan dengan motivasi yang benar dan kualitas yang terbaik untuk Tuhan. Dengan demikian hasil penelitian ini menunjukkan bahwa hasilnya sesuai dengan hipotesis yang telah peneliti ajukan sebelumnya.

\section{Kepustakaan}

[1] Alkitab Bahasa Indonesia Terjemahan Baru. Jakarta: LAI, 1993.

[2] Alkitab Bahasa Indonesia Terjemahan Lama. Jakarta: LAI, 1965.

[3] Alkitab Kabar Baik Dalam Bahasa Indonesia Sehari-hari.Jakarta: LAI, 1991.

\{4] Alkitab Penuntun Hidup Berkelimpahan. Diterjemahkan oleh Nugroho Hananiel Malang: LAI, Gandum Mas, 1994.

[5] Baas, H dan Soesastro Koesoemo, M. D. Memberi Secara Kristen. Jakarta: BPK Gunung Mulia, 1993.

[6] Bakker, F.L. Sejarah Kerajaan Allah I PL. Diterj. K. Siagian. Jakarta: BPK Gunung Mulia, 1993.

[7] Barclay, William. The Daily Study Bible Series The Gospel of Luke. Philadelphia: The Westminster Press, 1956.

[8] Boland, B. J. dan P. S. Naipospos.Tafsiran Alkitab Injil Lukas. Jakarta: BPK Gunung Mulia, 2012.

[9] Bovinck, J. H. Sejarah Kerajaan Allah 2 PB. Diterj. A. Simanjutak. Jakarta: BPK Gunung Mulia, 1993.

[10] Bungin, Burhan. Metodologi Penelitian Kuantitatif. Jakarta: Kencana, 2005.

[11] Burkett, Larry. Mengatur Keuangan dengan Bijak. Bandung : Yayasan Kalam Hidup,1993.

[12] Drane, John. Memahami Perjanjian Baru. Jakarta: BPK Gunung Mulia, 2012. 
[13] Drewes, B.F. Satu Injil Tiga Pekabar. Jakarta: BPK Gunung Mulia, 1982.

[14] Dyrness, William. Tema-tema Dalam Teologi Perjanjian Lama. Malang: Penerbit Gandum Mas, 2009.

[15] Gispen, W. H. dan lainnya. The Eerdmans Bible Dictionary. Grand Rapids, Michigan: William B. Eerdmans Publishing Company,1987.

[16] Green, Denis. Pembimbing Pada Pengenalan Perjanjian Lama. Malang: Penerbit Gandum Mas, 1995.

[17] Gulo,W. Metodologi Penelitian. Jakarta: PT. Gramedia Widia Sarana Indonesia, 1988.

[18] Halley, Henry H. Penuntun Ke Dalam Perjanjian Baru. Diterjemahkan oleh Siem Hong An dan Liem Khiem Soe. Surabaya: YAKIN, 1979.

[19] Hammond, Jeff. Persepuluhan. Jakarta: YPI Immanuel, 1991.

[20] Hartman, Jack. Percayakanlah Keuangan Anda Pada Allah.Yogyakarta: Yayasan Andi, 1989.

[21] Henry, Mattew dan lainnya. The Bethany Parallel Comentary On The New Testament. Minneapolis, Minnesota, USA: Bethany House Publisher, 1983.

[22] Herlianto. Teologi Sukses: Antara Allah dan Mamon. Jakarta: BPK Gunung Mulia, 1996.

[23] Jian,Wiharja. Persembahan yang Baik dan Benar. Bandung: Yayasan Kalam Hidup, 2001.

[24] Juanda DR. Pengaruh Kelas Pendalaman Iman Anak Lebak Arum (Piala) Terhadap Pertumbuhan Rohani Anak Usia 11-14 Tahun Di Kompleks Perumahan Lebak Arum Surabaya. Journal Kerusso. 2016;1(1):66-71.

[25] Marshall, I. H. Tafsiran Alkitab Masa Kini 3 Matius-Wahyu bag. Lukas. Diterjemahkan oleh
P.S. Naipospos. Jakarta: Yasayan Komunikasi Bina Kasih/OMF, 1992.

[26] Menzies, William W. Dan Stanley M. Horton. Doktrin Alkitab (dicetak untuk GSJA). Malang: Penerbit Gandum Mas, 2010.

[27] Mimery, Nehemiah. Persembahan dan Pemakaian Uang Tuhan. Jakarta: Mimerry Press, tt.

[28] Packer, J. I, Merrill C. Tenney dan William White, Jr. Ensiklopedi Fakta Alkitab

(Bible Almanac). Malang: Penerbit Gandum Mas, 2001.

[29] Perjanjian Baru Interlinear YunaniIndonesia dan Konkordansi Perjanjian Baru (PBIK) Jilid I. Jakarta: LAI, 2006.

[30] Perjanjian Baru Interlinear YunaniIndonesia dan Konkordansi Perjanjian Baru (PBIK) Jilid II. Jakarta: LAI, 2006.

[31] Poerwadaeminta,W. J. S. Kamus Umum Bahasa Indonesia. Jakarta: PN Balai Pustaka 1976.

[32] Post, Walter. M. Tafsiran Injil Markus. Bandung: Kalam Hidup, 1974.

[33] Salim, Peter dan Yenny Salim. Kamus Bahasa Indonesia Kontemporer. Jakarta: Modem English Press, 1991.

[34] Santoso, Benny dan Pontjoharyo Wiyono. Kebebasan Finansial dalam Perspektif Kristiani. Yogyakarta: ANDI, 2002.

[35] Sasmoko, Elizer. Metode Penelitian Pengukuran dan Analisa Data. Jakarta: Fine Book Collektion Dyulius Th. Bilo, 2005.

[36] Schultz, Samuel J. Pengantar Perjanjian Lama. Malang: Penerbit Gandum Mas, 1983.

[37] Selan, Ruth F. Menggali Keuangan Gereja.Bandung: Yayasan Kalam Hidup,1995. 
[38] Senduk, H.L. Ekonomi Allah Dalam Gerejanya. Jakarta: BPK Gunung Mulia, t.t.

[39] Spence, H.D.M. and Joseph S. Exell. The Pulpit Commentary Vol.16 Mark and Luke. Grand Rapids, Michigan: Wm. B. Eermans Publishing Company, 1983.

[40] Stambaugh, John dan David Balch. Dunia Sosial Kekristenan Mula-mula. Diterjemahkan oleh Stephen Suleeman. Jakarta: BPK Gunung Mulia, 1997.

[41] Sugiyono. Metode Penelitian Pendidikan Bandung: CV. Alfabeta, 2008.

[42] Sukardi, Imanuel.YM. Rahasia Investasi Tanpa Rugi. Surakarta: STT Indonesia, 2004.

[43] Swift, C. E. G. Tafsiran Alkitab Masa Kini 3 Matius-Wahyu bag. Markus. Diterjemahkan oleh Harun Hadiwijono. Jakarta: Yasayan Komunikasi Bina Kasih/OMF, 1992.

[44] Tafsiran Matthew Henry Injil Lukas. Diterjemahkan oleh Herdian Aprilani dkk Surabaya: Momentum, 2009.

[45] Tafsiran Matthew Henry Injil Markus. Diterjemahkan oleh Lanny Murtihardjono dkk. Surabaya: Momentum, 2007.

[46] Tenney, Merrill C. Survei Perjanjian Baru. Malang: Penerbit Gandum Mas, 1992.

[47] Teo, Steven. Persepuluhan Kunci Keberhasilan Finansial. Yogyakarta: ANDI , 2008.

[48] The Wycliffe Bible Commentary. Disunting oleh Charles F. Pfieiffer dan Everett F. Harrison. Vol.3 bag. Lukas. Malang: Penerbit Gandum Mas, 2001.

[49] Unger, Merrill F and Gary N. Larson. The Hodder Bible Handbook. London: Hodder and Stoughton, 1987.
[50] Vine, W.E. An Expository Dictionary of New Testament Words.New York: Thomas Nelson Publishers, 1939.

[51] Vriezen, Th. C. Agama Israel Kuna. Diterjemahkan oleh I. J. Cairns. Jakarta: BPK Gunung Mulia, 1983.

[52] Webster's New Collegiate Dictionary. Sprigfield, Mass, U.S.A: G. \& C. Merriam Co., Publishers, 1958.

[53] Wigram, George V. and Ralph D. Winter. The Word Study Concordance. Pasadena, California, USA: William Carey Library, 1978.

[54] Wolf, Herbert. Pengenalan Pentateukh. Malang: Penerbit Gandum Mas, 19 